\title{
Levels of genetic variation and covariation for Mimulus (Scrophulariaceae) floral traits
}

\author{
DAVID E. CARR* \& CHARLES B. FENSTER \\ Department of Botany, University of Maryland, College Park, MD 20742, U.S.A.
}

\begin{abstract}
In each of two populations of outcrossing Mimulus guttatus and selfing $M$. micranthus we quantified genetic variation for floral traits which previously were shown to be associated with mating system evolution in this genus at both the population and species levels. Both broad- and narrow-sense heritabilities and genetic correlations were measured in greenhouse experiments. For one population of $M$. guttatus, we investigated and found significant among family variation for autogamous seed-set in a pollinator-free environment, and this was weakly associated with stigma-anther separation. We observed intermediate to high levels of broad- and narrow-sense heritabilities for all traits, but genetic variation was consistently lower in the selfing species. Although characters correlated to stigma-anther separation or to day of first flower varied between populations and between taxa, there were consistently strong positive genetic correlations among traits associated with floral size.
\end{abstract}

Keywords: autogamy, genetic correlation, heritability, herkogamy, mating system, Mimulus.

\section{Introduction}

A plant's mating system has large consequences on the amount and pattern of genetic variation within and among populations (Wright, 1968; Loveless \& Hamrick, 1984). Commonly, the evolution of a mating system is associated with an extreme change in floral morphology. Selfers frequently have smaller flowers and reduced allocation to male function compared with their outcrossing congeners (Jain, 1976; Wyatt, 1988). The frequent evolution of selfing (Stebbins, 1950; Rollins, 1963; Lloyd, 1965; Barrett \& Shore, 1987; Barrett, 1988; Wyatt, 1988; Olmstead, 1989; Fenster \& Barrett, 1994) suggests that floral characters which determine mating systems are readily changed by natural selection.

The ability of the mating system to respond to natural selection depends on the amount of heritable or additive genetic variation for those floral traits which determine the degree of outcrossing (Darwin, 1859; Lande \& Arnold, 1983). Because floral traits often share developmental origins and similar constraints within developing buds (Steeves \& Sussex, 1989), their evolution may reflect indirect selection acting on correlated characters. There are surprisingly few studies, however, documenting patterns of genetic variation and covariation for floral characters associated with

*Correspondence. mating systems (Schoen, 1982; Hauptli \& Jain, 1985; Shore \& Barrett, 1990).

The genus Mimulus (Scrophulariaceae) is particularly appropriate for the study of mating system evolution, containing great diversity from highly selfing to highly outcrossing taxa (Ritland \& Ritland, 1989). Previous work (Macnair \& Cumbes, 1989; C. B. Fenster \& K. Ritland, unpublished data) demonstrated that the reduction of stigma-anther separation and flower size associated with the evolution of selfing in Mimulus is under polygenic and additive genetic control. Here we quantify genetic variation within populations for these same floral traits in two species of Mimulus, M. guttatus and M. micranthus.

Floral architecture in the two species differs considerably and is associated with differences in their mating systems. Large-flowered $M$. guttatus has a high pollen to ovule ratio, and depending on the population, the stigma is elevated an average of $2-4 \mathrm{~mm}$ above the anthers. This variation in stigma-anther separation among $M$. guttatus populations is positively correlated with variation among populations in autogamy rates (Dole, 1992). Outcrossing rates in M. guttatus populations range from 0.25 to 0.79 , averaging 52 per cent (Ritland, 1990). In contrast, the outcrossing rate of $M$. micranthus is only 16 per cent (Ritland \& Ritland, 1989). The stigma of this species lies between the two ranks of anthers, and relatively little is invested in its floral display or in pollen production (Ritland \& 
Ritland, 1989). Patterns of isozyme and cpDNA variation support the hypothesis that $M$. micranthus is recently derived from $M$. guttatus (Fenster \& Ritland, 1992).

The current investigation had three objectives. Firstly, we wished to determine whether floral characters associated with mating system differences among populations and among higher taxa could account for variation in autogamy rates in a pollinator-free greenhouse. Secondly, to determine if populations can respond to selection on the mating system, we quantified the amount of within population genetic variation for a number of floral characters including autogamy rate. Thirdly, to determine potential constraints on the evolution of floral morphology, we quantified genetic correlations among these characters. We examined the constancy or ability of genetic correlations to evolve by comparing genetic correlations among populations of $M$. guttatus and between the hypothesized progenitor $M$. guttatus and derivative $M$. micranthus.

\section{Materials and methods}

\section{Study organisms and sites}

Mimulus guttatus DC (Scrophulariaceae) is an annual to perennial herb widely distributed in western $\mathrm{N}$. America. Mimulus micranthus Heller is strictly annual and is restricted to the coastal range of central California (Munz \& Keck, 1959). Both species are found in moist open habitats such as stream edges and ephemeral pools. Seed families of $M$. guttatus were collected from two annual populations: $\mathrm{S}(n=23$ families) and T (approximately $10 \mathrm{~km}$ from S; $n=25$ families) both located in Tuolomne $\mathrm{Co}$, California. Population $\mathrm{T}$ consisted of approximately 100 flowering individuals while population $S$ numbered in the tens of thousands. Seed families of $M$. micranthus were collected from two populations: 301 ( $n=11$ families, Lake Co.) and 305 ( $n=$ six families, Mendicino Co.). Precise localities are provided in Appendix 1 of Fenster \& Ritland (1992).

\section{Heritability and correlates of autogamy}

To determine the relationships between stigma-anther separation, day of first flowering and flower size with autogamy rate, 27 pairs of full-sib families were generated from pair-wise reciprocal crosses using all fieldcollected families from population T of $M$. guttatus as parents at least once. Flowers were hand-pollinated on the day of anthesis and subsequently emasculated. Hand-pollinations typically yield hundreds of seeds. Approximately 30 seeds from each of the $54 \mathrm{~F}_{1}$ mater- nal families were sown into $68 \mathrm{~mm}$ square plastic pots and allowed to germinate under soil-saturated conditions with ambient daylight for 2 weeks. Four maternal families did not germinate in sufficient numbers and were omitted from the study. Ten seedlings from the remaining 50 maternal families were transplanted and arranged in 10 randomized blocks in a pollinator-free greenhouse ( $n=500$ plants, 27 full-sib families). This resulted in two full-sibs per block for all families except the four for which the reciprocal crosses were lost. Transplants were grown in $68 \mathrm{~mm}$ pots under soilsaturated conditions, and the natural photoperiod was extended to $18 \mathrm{~h}$ with high intensity sodium-vapour lights. Culturing conditions for other experiments in this study followed the same procedure.

On each plant we recorded the date of first flowering, and on each of the first four flowers we measured corolla width and the distance from the stigma to the highest rank of anthers. Corolla width was measured using digital calipers to the nearest $0.1 \mathrm{~mm}$, and stigma-anther separation was quantified to the nearest $0.5 \mathrm{~mm}$ using a calibrated wire. The first four fruits were collected prior to dehiscence, and the numbers of seeds per fruit were counted. Means for corolla width, stigma-anther separation and seed-set were calculated for each plant. Autogamous seed-set was also measured as the percentage of fruit setting at least one seed.

Among family variation for each of the four characters was tested using two-way ANOVA with block and full-sib family as random effects. The genetic variance for autogamous seed-set was quantified as the intraclass correlation $(t)$ which expresses the fraction of the total variation that is due to differences between family groups (Falconer, 1981). This genetic variance represents a broad-sense heritability as non-additive genetic variation and maternal effects may contribute to among family differences. The within family variance component was computed with and without the inclusion of the variance components due to block and the family $\times$ block interaction. Intraclass correlations for the other three characters were quantified in experiments described below. Standard errors of broad-sense heritabilities in this experiment and those outlined below were calculated as described in Becker (1975). The genetic correlations of date of first flowering, corolla width and stigma-anther separation with autogamous seed-set were estimated using the Spearman rank correlations among family means for these traits ( $n=27$ families). The functional relationships between the characters corolla width and stigma-anther separation distance with autogamous seed-set were examined by performing Spearman rank correlations using all flowers across all individuals as the individual data points ( $n=1924$ flowers). 


\section{Heritabilities of other floral characters}

To quantify additive genetic variation (narrow-sense heritabilities) in $M$. guttatus we performed separate parent-offspring regressions for the $\mathrm{S}$ and $\mathrm{T}$ populations. We sowed field-collected seed from 23 and 25 field-collected families from the $S$ and $T$ populations, respectively. Within each population, we reciprocally crossed the 23-25 pairs of parents using randomly selected individuals from each family. Five seedlings were randomly chosen from each $F_{1}$ maternal family, proving a total of 10 offspring from each of the 23 and 25 crosses $(n=230$ and 250 progeny for $\mathrm{S}$ and $\mathrm{T}$ populations, respectively). Offspring were grown in five randomized blocks. One progeny per maternal family was grown in each block, resulting in two members of each full-sib family planted per block. The parental populations were grown simultaneously, and the offspring from $S$ and $T$ were grown 1 month apart. Otherwise conditions (temperature, photoperiod, watering and fertilization) were identical for both populations.

The number of days to the first flower was scored for each plant. Using digital calipers we measured the following traits which have been demonstrated to be associated with mating system evolution in $M$. guttatus: corolla width, corolla length, low stamen height, high stamen height, pistil length, style length, ovary length (pistil length minus style length) and stigma-anther separation (pistil length minus high stamen height). Note that a stigma-anther separation $<0$ indicates that the stigma was below the highest rank of anthers. We measured the first four flowers for the parental and offspring generations for population $\mathrm{T}$ and the offspring generation of population S. Only the first flower was measured for the parental generation of population $S$.

We estimated heritabilities in the two populations by computing both single and mid-parent offspring regressions (Falconer, 1981). For each individual plant, means from the four measured flowers were calculated for each character. Single parent offspring regressions were calculated based on the means of the 46 and 50 sire full-sib or maternal full-sib offspring for populations $\mathrm{S}$ and $\mathrm{T}$, respectively. Mid-parent regressions were calculated based on the means of the 23 or 25 full-sib families. The standard errors of the heritabilities based on single parent and mid-parent regressions are twice the standard error and the standard error of the regression, respectively (Falconer, 1981). For comparative purposes with $M$. micranthus we also calculated broad-sense heritabilities for $M$. guttatus based on the variance among full-sib families in the offspring generations. As in the autogamy experiment, among family variation was estimated using two-way ANOVA with block and family as random effects. The within family variance component was computed with and without the inclusion of the variance components due to block and the family $\times$ block interaction. Confidence limits lower than 0 or greater than 1 were set arbitrarily at 0 and 1 , respectively.

To quantify genetic variation for the same floral characters in $M$. micranthus we examined among family variation for 11 and six families from populations 301 and 305, respectively. Families from populations 301 and 305 had been maintained in environmental growth chambers for one and three generations, respectively. One seedling per family was grown in each of five randomized blocks and measurements were made on the first four flowers. Among family variation was estimated using two-way ANOVA with block and family as random effects. Because we had no replication of families within a block, the family $\times$ block interaction is included in the error term. Broad-sense heritabilities were estimated with and without the variance component due to block in the estimate of total phenotypic variation. The intraclass correlation was not multiplied by two as sibs in a selfer are likely to share many of their genes in common.

To determine whether populations and species would respond proportionally to selection on these traits, we transformed additive genetic variation, $\mathrm{V}_{\mathrm{A}}$, and total genetic variation, $V_{G}$, to a dimensionless scale by dividing by the mean for each trait (Charlesworth, 1984; Houle, 1992). This resulted in coefficients of variation for additive and total genetic variation $\left(\mathrm{CV}_{\mathrm{A}}=100\left(\mathrm{~V}_{\mathrm{A}}^{0.5} / \overline{\mathrm{X}}\right)\right.$ and $\left.\mathrm{CV}_{\mathrm{G}}=100\left(\mathrm{~V}_{\mathrm{G}}{ }^{0.5} / \overline{\mathrm{X}}\right)\right)$.

\section{Genetic correlations}

Genetic correlations among the floral characters were quantified using two methods. Firstly, for M. micranthus, Pearson correlations among the floral characters were calculated based on character means from the same families used to quantify among family variation. Secondly, genetic correlations based on the segregation of loci with additive effect was estimated in $M$. guttatus by using covariances derived from the parent-offspring regressions in the $\mathrm{S}$ and $\mathrm{T}$ populations using the following formula (Becker, 1975):

$r_{\mathrm{G}}=\frac{\operatorname{cov}\left(x_{1} z_{2}\right)+\operatorname{cov}\left(x_{2} z_{1}\right)}{2 \sqrt{\operatorname{cov}\left(x_{1} z_{1}\right) \operatorname{cov}\left(x_{2} z_{2}\right)}}$,

where $x_{1}$ is character $x$ measured on the parent, $z_{2}$ is character $z$ measured on the offspring, $x_{2}$ is character $x$ measured on the offspring and $z_{1}$ is character $z$ measured on the parent. The 95 per cent confidence 
intervals of the additive genetic correlations were estimated by calculating the standard errors (Falconer, 1981) and multiplying them by the appropriate $t$-value. The correlations were considered to differ significantly from zero if the confidence interval did not include zero.

We note that there is a considerable need for the development of statistical techniques for comparing genetic correlation matrices (Shaw, 1991, 1992; Cowley \& Atchley, 1992). There is a consensus that large numbers of families (more than 100) are needed for precise estimates of genetic correlations (Klein et al., 1973). Because our estimates are based on upwards of 25 families per population, we take a conservative approach and consider individual genetic correlations to differ significantly if their correlation estimates are not included within each others' 95 per cent confidence intervals. We also compare the genetic variance-covariance matrices by conducting cell by cell regression analyses (Arnold, 1992). Matrices are considered to be identical if points fall on a 45 degree line through the origin. Matrices are considered to be proportional (scalar multiples of each other) if the $r^{2}$ is high but the slope of the regression differs from one. Correlations of the floral characters with ovary and style length were not conducted because these two characters are components of pistil length.

\section{Assumptions}

A number of factors may cause us to overestimate the amount of genetic variation in natural populations and hence the magnitude of the potential response to selection. Firstly, among family genetic variation may include non-additive components of variation which will not contribute to a response to selection. Secondly, our measurements were conducted under controlled conditions and minimized the contribution of environment to phenotypic variation. It is likely that under field conditions, the environmental contribution would be much greater, thus resulting in lower heritabilities and lower response. Furthermore, because the greenhouse represents a novel environment, a genotype $\times$ novel environment interaction may be contributing to the estimates of genetic variation (Mitchell-Olds, 1986). Variation in prior inbreeding among individuals may contribute to inflated estimates of additive genetic variation if the traits we measured are influenced by inbreeding depression (Wright \& Cockerham, 1985). Mimulus guttatus and M. micranthus selfed progeny do suffer from significant amounts of inbreeding depression (Ritland \& Ganders, 1987; Dole \& Ritland, 1993; Willis, 1993; Carr \& M. R. Dudash, unpublished data). The fixation index, $F$ (Wright, 1969), which measures the correlation of unit- ing gametes and is a measure of inbreeding, is generally low in $M$. guttatus populations (mean $F=0.13$; Ritland, $1990)$ but is high in $M$. micranthus $(F=0.73$; Ritland \& Ritland, 1989). Our design does not allow us to distinguish between the role of pleiotropy and linkage as sources of genetic correlations among traits. Linkage is likely to play a larger role in trait correlations in $M$. micranthus because of the lower effective rate of recombination caused by selfing (Bodmer \& Parsons, 1962).

\section{Results}

\section{Floral correlates of autogamy}

Twenty-four per cent of the flowers produced at least one seed. The mean number of seeds per fruit, 15.8, was a small fraction of the typical full seed-set per fruit but the variance around this mean, 1816.8, was extremely high with most flowers setting no seed and some setting over 400 . There was significant among family variation for autogamy rates based on both average seed set per flower $\left(F_{26,447}=6.64, P<0.0001\right)$ and fruit set $\left(F_{26,447}=7.25, P<0.0001\right)$. In addition stigma-anther separation $\left(F_{26,463}=13.63, P<0.0001\right)$, corolla width $\left(F_{26,463}=4.95, P<0.0001\right)$ and date of first flowering $\left(F_{26,463}=2.86, P<0.0001\right)$ also demonstrated significant among family variation. We observed only a weak association of autogamous seed-set with day of first flowering, corolla width or stigma-anther separation (Table 1) based on family means and a weak correlation with stigma-anther separation using flowers as the unit of replication (Spearman rank $r=-0.107, P<0.0001)$. A relationship between autogamous seed-set and stigma-anther separation may have been difficult to determine using correlation analysis if only the extreme classes of stigma-anther separation exhibited differences in autogamous seedset. Thus we contrasted autogamous seed-set between the 10 maternal families which had the highest and lowest stigma-anther separation. A Mann-Whitney $U$ test revealed a small but significant difference between the two sets of maternal families (mean seed-set of 10 families with shortest stigma-anther separation $=24.9$ seeds/flower; mean seed-set of 10 families with greatest stigma-anther separation $=11.3$ seeds/flower; $Z=-2.117, P<0.05)$. However, this relationship was not observed when the contrast was restricted to the five full-sib families with the lowest and highest stigma-anther separation.

\section{Heritability of autogamy and floral traits}

Populations within each species did not differ in their phenotypic means (Table 2). Narrow-sense heritabilities 
estimated from single parent regressions revealed little difference between dam and sire effects. Except for the character corolla width in population $\mathrm{T}$, all traits demonstrated significant heritabilities that were moderate to high (Table 3). Based on mid-parent regressions, heritabilities in population $\mathrm{S}$ exceeded those of population $\mathrm{T}$ by two standard errors for all traits except stigma-anther separation.

Broad-sense heritabilities measure the magnitude of the among family component of variation relative to the total phenotypic variation. In our design variance components due to block and the interaction between block and family can be partitioned from the within family variation. Block effects were generally significant but the variance component due to block was always small. Inclusion of the block effect in the within family variance component decreased heritabilities by one to two per cent. Only broad-sense heritabilities estimated without variation due to block included in the error term are reported here in order to estimate the maximum determination of phenotype by geno- type. Effects due to block $\times$ family interaction were tested and found to be nonsignificant for all characters but one. In the exception, date of first flowering in the $\mathrm{T}$ population, broad-sense heritability calculated with and without the family $\times$ block interaction included in the error term differed by only five per cent. We report only the heritability estimate based on the inclusion of the interaction in the error mean square.

An intermediate broad-sense heritability was observed for autogamy rates in the T population of $M$. guttatus (Table 4). Broad-sense heritabilities for the other traits were high in both populations of $M$. guttatus and generally exceeded the narrow-sense heritabilities (Table 4). For $M$. micranthus broad-sense heritabilities for day of first flower, corolla width and corolla length were equivalent to broad-sense heritabilities measured in the two $M$. guttatus populations (Table 4). Population 305 of $M$. micranthus also demonstrated levels of genetic variation for the two stamen heights similar to those observed in population $\mathrm{T}$ of $M$. guttatus. Broad-sense heritabilities were gener-

Table 1 Spearman rank correlations of three floral characters with autogamy as measured by seed-set and fruit-set based on $27 \mathrm{M}$. guttatus families from the $T$ population. All correlations are nonsignificant at the $P=0.05$ level

\begin{tabular}{lcr}
\hline Character & $\begin{array}{c}\text { Correlation with } \\
\text { autogamous seed-set }\end{array}$ & $\begin{array}{r}\text { Correlation } \\
\text { with fruit-set }\end{array}$ \\
\hline Day of first flower & -0.048 & -0.194 \\
Corolla width & 0.046 & 0.075 \\
Stigma-anther separation & -0.175 & -0.103 \\
\hline
\end{tabular}

Table 2 Means (and variances) for nine traits from two populations of M. guttatus and two populations of $M$. micranthus. Day of first flower is measured in days; all other traits are measured in $\mathrm{mm}$

\begin{tabular}{lrrrrrrr}
\hline & \multicolumn{3}{c}{ M. guttatus } & \multicolumn{3}{c}{ M. micranthus } \\
\cline { 2 - 6 } Trait & \multicolumn{2}{c}{$\mathrm{S}$} & \multicolumn{2}{c}{$\mathrm{T}$} & \multicolumn{2}{c}{301} & 305 \\
\hline Day of first flower & $41.46(67.99)$ & $51.71(44.73)$ & $39.08(33.29)$ & $48.57(8.46)$ \\
Corolla width & $22.43(19.12)$ & $24.03(15.06)$ & 6.34 & $(0.39)$ & $8.16(0.38)$ \\
Corolla length & $21.41(10.23)$ & 22.87 & $(5.53)$ & 8.12 & $(0.31)$ & $9.58(0.39)$ \\
Stamen height & & & & & & & \\
$\quad$ Low & 13.27 & $(2.76)$ & 14.51 & $(2.15)$ & 6.17 & $(0.19)$ & $7.02(0.24)$ \\
$\quad$ High & 15.50 & $(3.44)$ & 16.62 & $(2.69)$ & 7.01 & $(0.20)$ & $8.04(0.20)$ \\
Pistil length & 18.43 & $(3.99)$ & 19.52 & $(3.79)$ & 5.40 & $(0.17)$ & $6.30(0.06)$ \\
Ovary length & 5.14 & $(0.54)$ & 5.22 & $(0.95)$ & 3.39 & $(0.06)$ & $4.37(0.03)$ \\
Style length & 13.29 & $(2.13)$ & 14.39 & $(2.20)$ & 2.01 & $(0.03)$ & $1.93(0.01)$ \\
Stigma-anther & 2.93 & $(1.74)$ & 2.95 & $(1.74)$ & -1.62 & $(0.04)$ & $-1.73(0.16)$ \\
$\quad$ separation & & & & & & & \\
\hline
\end{tabular}

Means and variances were calculated across individuals in the offspring generation. 
Table 3 Narrow-sense heritabilities ( \pm 95 per cent confidence limits) based on three different regressions (dam, sire and midparent) for eight floral characters in two populations of $M$. guttatus

\begin{tabular}{|c|c|c|c|c|c|c|}
\hline \multirow[b]{2}{*}{ Character } & \multicolumn{3}{|c|}{ Population S } & \multicolumn{3}{|c|}{ Population T } \\
\hline & Dam & Sire & Mid-parent & Dam & Sire & Mid-parent \\
\hline Day of first flower & $\begin{array}{l}0.924 * * * \\
(0.548)\end{array}$ & $\begin{array}{c}0.726^{*} \\
(0.516)\end{array}$ & $\begin{array}{l}0.631^{* *} \\
(0.440)\end{array}$ & $\begin{array}{c}0.594 * * \\
(0.401)\end{array}$ & $\begin{array}{l}0.655^{* * *} \\
(0.414)\end{array}$ & $\begin{array}{c}0.374^{*} \\
(0.308)\end{array}$ \\
\hline Corolla width & $\begin{array}{c}0.313 \\
(0.360)\end{array}$ & $\begin{array}{r}0.442^{*} \\
(0.370)\end{array}$ & $\begin{array}{r}0.376^{*} \\
(0.330)\end{array}$ & $\begin{array}{c}0.296^{*} \\
(0.266)\end{array}$ & $\begin{array}{l}0.0 \\
(0.296)\end{array}$ & $\begin{array}{c}0.157 \\
(0.330)\end{array}$ \\
\hline Corolla length & $\begin{array}{c}0.523^{*} \\
(0.398)\end{array}$ & $\begin{array}{c}0.652^{* *} \\
(0.414)\end{array}$ & $\begin{array}{l}0.576^{\text {*** }} \\
(0.330)\end{array}$ & $\begin{array}{c}0.273 \\
(0.309)\end{array}$ & $\begin{array}{c}0.356^{*} \\
(0.320)\end{array}$ & $\begin{array}{c}0.289 \\
(0.296)\end{array}$ \\
\hline Stamen height (Low) & $\begin{array}{r}0.575^{*} \\
(0.474)\end{array}$ & $\begin{array}{c}0.728^{* *} \\
(0.492)\end{array}$ & $\begin{array}{c}0.757^{* *} \\
(0.412)\end{array}$ & $\begin{array}{l}0.524^{* *} \\
(0.373)\end{array}$ & $\begin{array}{c}0.488^{*} \\
(0.379)\end{array}$ & $\begin{array}{c}0.440^{*} \\
(0.304)\end{array}$ \\
\hline Stamen height (High) & $\begin{array}{c}0.640^{*} \\
(0.480)\end{array}$ & $\begin{array}{c}0.792^{* * *} \\
(0.500)\end{array}$ & $\begin{array}{l}0.875^{* * * *} \\
(0.422)\end{array}$ & $\begin{array}{c}0.477 * * \\
(0.327)\end{array}$ & $\begin{array}{c}0.412^{*} \\
(0.338)\end{array}$ & $\begin{array}{c}0.410^{*} \\
(0.288)\end{array}$ \\
\hline Pistil length & $\begin{array}{c}0.671^{*} \\
(0.244)\end{array}$ & $\begin{array}{l}0.776^{* *} \\
(0.502)\end{array}$ & $\begin{array}{l}0.809^{* * *} \\
(0.408)\end{array}$ & $\begin{array}{c}0.274 \\
(0.312)\end{array}$ & $\begin{array}{c}0.185 \\
(0.331)\end{array}$ & $\begin{array}{c}0.232 \\
(0.322)\end{array}$ \\
\hline Ovary length & $\begin{array}{c}0.457^{*} \\
(0.436)\end{array}$ & $\begin{array}{c}0.688^{* *} \\
(0.415)\end{array}$ & $\begin{array}{l}0.805^{* * *} \\
(0.692)\end{array}$ & $\begin{array}{c}0.153 \\
(0.270)\end{array}$ & $\begin{array}{c}0.193 \\
(0.273)\end{array}$ & $\begin{array}{c}0.243 \\
(0.590)\end{array}$ \\
\hline Style length & $\begin{array}{c}0.611^{*} \\
(0.488)\end{array}$ & $\begin{array}{r}0.627^{*} \\
(0.486)\end{array}$ & $\begin{array}{c}0.662^{* *} \\
(0.404)\end{array}$ & $\begin{array}{c}0.387^{*} \\
(0.337)\end{array}$ & $\begin{array}{c}0.219 \\
(0.359)\end{array}$ & $\begin{array}{c}0.314 \\
(0.346)\end{array}$ \\
\hline $\begin{array}{l}\text { Stigma-anther } \\
\text { separation }\end{array}$ & $\begin{array}{c}0.345^{*} \\
(0.340)\end{array}$ & $\begin{array}{c}0.477^{* *} \\
(0.330)\end{array}$ & $\begin{array}{c}0.378^{* *} \\
(0.288)\end{array}$ & $\begin{array}{l}0.763^{* * *} \\
(0.302)\end{array}$ & $\begin{array}{l}0.677^{* * * *} \\
(0.313)\end{array}$ & $\begin{array}{l}0.557^{* * *} \\
(0.270)\end{array}$ \\
\hline
\end{tabular}

${ }^{*} P \leqslant 0.05,{ }^{* *} P \leqslant 0.01,{ }^{* * *} P \leqslant 0.001$.

Table 4 Broad-sense heritabilities (and 95 per cent confidence intervals) for ten floral characters in each of two populations of M. micranthus and M. guttatus

\begin{tabular}{|c|c|c|c|c|}
\hline \multirow[b]{2}{*}{ Character } & \multicolumn{2}{|c|}{ M. micranthus } & \multicolumn{2}{|c|}{ M. guttatus } \\
\hline & Population 301 & Population 305 & Population S & Population T \\
\hline Day of first flower & & & $\begin{array}{c}0.590^{* * *} \\
(0339-0.981)\end{array}$ & $\begin{array}{c}0.640^{* * *} \\
(0379-0998)\end{array}$ \\
\hline \multirow{2}{*}{ Corolla width } & $\begin{array}{c}(0.356-0.846) \\
0.294\end{array}$ & $\begin{array}{l}(0.0-0.6 / 5) \\
0.196\end{array}$ & $\begin{array}{l}(0.339-0.981) \\
0.800^{* * *}\end{array}$ & $\begin{array}{c}(0.379-0.998) \\
0.280^{* * * *}\end{array}$ \\
\hline & $(0.022-0.605)$ & $(0.0-0.709)$ & $(0.491-1.0)$ & $(0.125-0.626)$ \\
\hline \multirow[t]{2}{*}{ Corolla length } & $0.322^{* *}$ & $0.540^{* *}$ & $0.910^{* * *}$ & $0.450^{* * *}$ \\
\hline & $(0.046-0.633)$ & $(0.169-0.884)$ & $(0.582-1.0)$ & $(0.281-0.869)$ \\
\hline \multirow[t]{2}{*}{ Stamen height (Low) } & $0.245^{*}$ & $0.619^{* * *}$ & $0.910^{* * *}$ & $0.760^{* * *}$ \\
\hline & $(0.0-0.564)$ & $(0.251-0.910)$ & $(0.585-1.0)$ & $(0.515-1.0)$ \\
\hline \multirow[t]{2}{*}{ Stamen height (High) } & $0.236^{*}$ & $0.578 * * *$ & $0.940^{* * *}$ & $0.710^{* * *}$ \\
\hline & $(0.0-0.556)$ & $(0.207-0.898)$ & $(0.611-1.0)$ & $(0.458-1.0)$ \\
\hline \multirow[t]{2}{*}{ Pistil length } & $0.268^{*}$ & 0.086 & $0.920^{* * *}$ & $0.410^{* * *}$ \\
\hline & $(0.012-0.593)$ & $(0.0-0.612)$ & $(0.604-1.0)$ & $(0.236-0.805)$ \\
\hline \multirow[t]{2}{*}{ Ovary length } & 0.165 & 0.059 & $0.977^{* * *}$ & $0.332^{* * *}$ \\
\hline & $(0.0-0.440)$ & $(0.0-0.459)$ & $(0.642-1.0)$ & $(0.178-0.714)$ \\
\hline \multirow[t]{2}{*}{ Style length } & $0.367^{* *}$ & 0.0 & $0.860^{* * *}$ & $0.450 * * *$ \\
\hline & $(0.093-0.681)$ & $(0.0-0.339)$ & $(0.561-1.0)$ & $(0.246-0.819)$ \\
\hline \multirow[t]{2}{*}{ Stigma-anther separation } & 0.022 & $0.449^{* *}$ & $0.560^{* *}$ & $0.720^{* * *}$ \\
\hline & $(0.0-0.309)$ & $(0.101-0.855)$ & $(0.366-1.0)$ & $(0.427-1.0)$ \\
\hline Autogamy rate & - & - & - & $0.452^{* * *}$ \\
\hline
\end{tabular}

$* P \leqslant 0.05,{ }^{* *} P \leqslant 0.01,{ }^{* * *} P \leqslant 0.001$. 
ally much lower in $M$. micranthus for characters measured on the gynoecium.

Comparison of $\mathrm{CV}_{\mathrm{A}}$ between the two M. guttatus populations revealed that the $\mathrm{S}$ population had consistently higher additive genetic variation (Table 5). Except for the characters date of first flower and style length, both $M$. micranthus populations showed lower $\mathrm{CV}_{\mathrm{G}}$ than either $M$. guttatus population and were particularly low in androecium and gynoecium characters (Table 5).

\section{Correlations}

In $M$. micranthus most traits associated with floral size showed strong positive correlations (Table 6). Most characters also showed positive correlations with date of first flower. The characters most strongly correlated with stigma-anther separation were stamen heights. As in $M$. micranthus, both populations of $M$. guttatus demonstrated strong positive correlations among traits associated with floral size (Table 7). Only population S showed strong correlations with date of first flower. The two populations also differed in that stigma-anther separation in population $S$ was most strongly correlated with pistil length, whereas in population $\mathrm{T}$ it was most strongly correlated with stamen height. The correlations between the floral characters and date of first flower in population $\mathrm{S}$ exceeded those same correlation estimates in population $\mathrm{T}$ by more than two standard errors, and the correlations of stigma-anther separation distance with stamen heights also differed between the two populations by more than two standard errors.

The similarity among genetic variance-covariance matrices is demonstrated in Fig. 1. We did not include covariances involving day of first flower because the genetic correlations showed highly significant differences among populations. Thus we were interested in examining whether other traits varied among populations as well. The greatest identity between populations was observed for the two $M$. micranthus populations. For the between species comparison, the cell by cell correlations between the genetic correlation matrices of the $M$. micranthus populations with population $\mathrm{S}$ of $M$. guttatus had the least residual error, indicating strong proportionality among the matrices. In contrast, comparisons involving the T population of $M$. guttatus demonstrated weaker proportionality.

\section{Discussion}

Mating system variation among species in the genus Mimulus is strongly associated with variation in herkogamy and flower size (Ritland \& Ritland, 1989). The principal goals of our study were to determine levels of genetic variation and covariation for these same floral traits in each of two populations of the outcrossing $M$. guttatus and selfing $M$. micranthus. We generally observed high levels of genetic variation and strong positive correlations among traits associated with floral size. These results suggest that Mimulus populations can readily respond to selection, but some characters may not evolve independently.

Table 5 Coefficients of variation for additive $\left(\mathrm{CV}_{\mathrm{A}}\right)$ and total genetic $\left(\mathrm{CV}_{\mathrm{G}}\right)$ components of variation for two populations of M. guttatus and two populations of M. micranthus $\left(\mathrm{CV}_{\mathrm{G}}\right.$ only)

\begin{tabular}{|c|c|c|c|c|c|c|}
\hline \multirow[b]{2}{*}{ Trait } & \multicolumn{4}{|c|}{ M. guttatus } & \multicolumn{2}{|c|}{ M. micranthus } \\
\hline & $\stackrel{\mathrm{S}}{\mathrm{CV}_{\mathrm{A}}}$ & $\begin{array}{c}\mathrm{T} \\
\mathrm{CV}_{\mathrm{A}}\end{array}$ & $\begin{array}{c}\mathrm{S} \\
\mathrm{CV}_{\mathrm{G}}\end{array}$ & $\begin{array}{c}\mathrm{T} \\
\mathrm{CV}_{\mathrm{G}}\end{array}$ & $\begin{array}{l}301 \\
\mathrm{CV}_{\mathrm{G}}\end{array}$ & $\begin{array}{l}305 \\
\mathrm{CV}_{\mathrm{G}}\end{array}$ \\
\hline Date of first flower & 15.798 & 7.910 & 15.276 & 10.347 & 11.940 & 1.913 \\
\hline Corolla width & 11.954 & 6.399 & 17.437 & 8.546 & 5.341 & 3.344 \\
\hline Corolla length & 11.338 & 5.528 & 14.251 & 6.898 & 3.891 & 4.790 \\
\hline \multicolumn{7}{|l|}{ Stamen height } \\
\hline Low & 10.893 & 6.703 & 11.943 & 8.810 & 3.497 & 5.491 \\
\hline High & 11.193 & 6.319 & 11.601 & 8.315 & 3.099 & 4.229 \\
\hline Pistil length & 9.748 & 4.804 & 10.396 & 6.386 & 6.051 & 1.140 \\
\hline Ovary length & 12.827 & 9.204 & 14.131 & 10.759 & 2.935 & 0.963 \\
\hline Style length & 8.935 & 5.792 & 10.184 & 6.934 & 5.220 & 0.0 \\
\hline $\begin{array}{l}\text { Stigma-anther } \\
\text { separation }\end{array}$ & 27.679 & 33.372 & 33.690 & 37.942 & 1.831 & 15.493 \\
\hline
\end{tabular}


Table 6 Genetic correlations among floral characters based on family means for two populations of $M$. micranthus

\begin{tabular}{|c|c|c|c|c|c|c|}
\hline & \multirow{2}{*}{$\begin{array}{l}\text { Corolla } \\
\text { width }\end{array}$} & \multirow{2}{*}{$\begin{array}{l}\text { Corolla } \\
\text { length }\end{array}$} & \multirow{2}{*}{$\begin{array}{l}\text { Pistil } \\
\text { length }\end{array}$} & \multicolumn{2}{|c|}{ Stamen height } & \multirow{2}{*}{$\begin{array}{l}\text { Stigma-anther } \\
\text { separation }\end{array}$} \\
\hline & & & & Low & High & \\
\hline \multicolumn{7}{|l|}{ Population 301} \\
\hline $\begin{array}{l}\text { Date of first flower } \\
\text { Corolla width } \\
\text { Corolla length } \\
\text { Pistil length } \\
\text { Stamen height (Low) } \\
\text { Stamen height (High) }\end{array}$ & 0.50 & $\begin{array}{l}0.26 \\
0.93^{* * *}\end{array}$ & $\begin{array}{l}0.36 \\
0.94^{* * *} \\
0.92^{* * *}\end{array}$ & $\begin{array}{l}0.42 \\
0.94^{* * *} \\
0.96^{* * *} \\
0.90^{* * *}\end{array}$ & $\begin{array}{l}0.50 \\
0.95^{* * *} \\
0.95^{* * *} \\
0.91^{* * *} \\
0.91^{* * *}\end{array}$ & $\begin{array}{r}-0.40 \\
0.19 \\
-0.24 \\
0.04 \\
-0.34 \\
-0.37\end{array}$ \\
\hline \multicolumn{7}{|l|}{ Population 305} \\
\hline $\begin{array}{l}\text { Date of first flower } \\
\text { Corolla width } \\
\text { Corolla length } \\
\text { Pistil length } \\
\text { Stamen height (Low) } \\
\text { Stamen height (High) }\end{array}$ & -0.35 & $\begin{array}{c}-0.23 \\
0.96^{* *}\end{array}$ & $\begin{array}{r}-0.63 \\
0.44 \\
0.43\end{array}$ & $\begin{array}{l}-0.08 \\
0.88^{*} \\
0.97^{* *} \\
0.36\end{array}$ & $\begin{array}{l}-0.10 \\
0.87^{*} \\
0.96^{* *} \\
0.44 \\
0.99^{* * *}\end{array}$ & $\begin{array}{c}-0.28 \\
-0.70 \\
-0.78^{+} \\
0.13 \\
-0.88^{*} \\
-0.84^{*}\end{array}$ \\
\hline
\end{tabular}

$+0.10 \geqslant P>0.05,{ }^{*} P \leqslant 0.05,{ }^{* *} P \leqslant 0.01,{ }^{* * *} P \leqslant 0.001$.

\section{Herkogamy and autogamy}

Our results indicate a strong genetic component to both the degree of stigma-anther separation and the probability and quantity of autogamous seed-set within populations of the highly outcrossing $M$. guttatus. Although the range of stigma-anther separation observed in our experiment is similar to the range observed among populations and taxa differing greatly in outcrossing rate (Ritland \& Ritland, 1989; Dole, 1992), our results at both the among family and the among flower levels suggest only a weak association between herkogamy and autogamous seed-set. Dole (1990) has demonstrated that autogamous pollinations can occur as the corolla is shed in $M$. guttatus and that corolla abscission can account for the majority of autogamous seed set in a pollinator-free environment. Because corollas were not prevented from abscising in our experiment, this type of delayed selfing likely contributed to autogamous seed-set and may have obscured any prior relationship between herkogamy and selfing rate. The environment can have a strong influence on selfing rates in natural populations of plants (Hauptli \& Jain, 1985; Barrett et al., 1992; Holtsford \& Ellstrand, 1992), and mechanisms of delayed selfing and prior selfing (Lloyd, 1979) may have different importance depending on environmental factors. Dudash \& Ritland (1991) found no evidence of increased autogamy in flowers that were given the opportunity for delayed self-pollination in natural populations of $M$. guttatus, indicating that most of the self-fertilizations occur prior to corolla abscission in these populations.

\section{Genetic variation}

Estimates of broad-sense heritabilities in $M$. guttatus were consistently higher than the estimates for narrowsense heritabilities suggesting a small but significant non-additive genetic component. Crosses between selfing and outcrossing Mimulus taxa also reveal a limited role of non-additive genetic variation to the differentiation of traits at the species level (Macnair \& Cumbes, 1989; Fenster \& Ritland, 1994). The contribution of epistasis was smaller than dominance in these studies. Our results cannot distinguish between the contributions of dominance and epistasis to the broad-sense heritabilities, but inbreeding does lead to decreased flower size in $M$. guttatus (Willis, 1991), suggesting a significant contribution of dominance to non-additive genetic variation.

The ample genetic variation for floral size and herkogamy observed in the present study and in Dole (1992) suggests that traits such as attractive structures and those more directly associated with the degree of outcrossing are capable of responding to selection in natural $M$. guttatus populations. Fenster \& Ritland 
Table 7 Genetic correlations among floral characters based on mid-parent-offspring regression for two populations of $M$. guttatus

\begin{tabular}{|c|c|c|c|c|c|c|}
\hline & \multirow{2}{*}{$\begin{array}{l}\text { Corolla } \\
\text { width }\end{array}$} & \multirow{2}{*}{$\begin{array}{l}\text { Corolla } \\
\text { length }\end{array}$} & \multirow{2}{*}{$\begin{array}{l}\text { Pistil } \\
\text { length }\end{array}$} & \multicolumn{2}{|c|}{ Stamen height } & \multirow{2}{*}{$\begin{array}{l}\text { Stigma-anther } \\
\text { separation }\end{array}$} \\
\hline & & & & Low & High & \\
\hline Date of first flower & $0.82^{* * * *}$ & $0.75^{\text {米炡 }}$ & $0.68^{* * * * *}$ & $0.78^{* * * * *}$ & $0.74^{* * * *}$ & -0.01 \\
\hline Corolla width & & $0.91^{* * * * *}$ & $0.86^{* * *}$ & $0.84^{* * * *}$ & $0.82 * * *$ & 0.27 \\
\hline Stamen height (Low) & & & & & $0.70^{\text {*小将冰 }}$ & 0.10 \\
\hline Stamen height (High) & & & & & & 0.01 \\
\hline \multicolumn{7}{|l|}{ Tpopulation } \\
\hline Date of first flower & -0.31 & $-0.58^{*}$ & -0.30 & -0.34 & -0.43 & 0.23 \\
\hline Stamen height (High) & & & & & & $-0.67^{* * * *}$ \\
\hline
\end{tabular}

$* 95 \%$ confidence interval (C.I.) does not include zero, ${ }^{* * 99 \% ~ C . I . ~ d o e s ~ n o t ~ i n c l u d e ~ z e r o, ~}{ }^{* * *} 99.9 \%$ C.I. does not include zero.

(unpublished data) have estimated strong direct and indirect selection operating on floral size and herkogamy in natural populations of $M$. guttatus. Our observation of continuous variation for all floral characters suggests that there is polygenic control of floral traits associated with the mating system. Better evidence for polygenic control of floral traits is provided by interspecific crosses between small-flowered selfing and large-flowered outcrossing Mimulus (Macnair \& Cumbes, 1989; Fenster \& Ritland, 1994). Thus our results suggest that the observed differences among populations of Mimulus species and the larger phenotypic shifts between species in the genus may reflect the action of selection acting on polygenic variation.

There is evidence that outcrossing occasionally can evolve from selfing taxa (Barrett \& Shore, 1987; Olmstead, 1989). Mimulus micranthus contains significant genetic variation for many floral characters, suggesting that floral size, herkogamy and presumably mating system could also respond to selection in this selfing species, but the $\mathrm{CV}_{\mathrm{G}}$ for floral traits was, on average, three times lower than in $M$. guttatus. The broad-sense heritabilities and $\mathrm{CV}_{\mathrm{G}}$ for gynoecium characters are particularly low when contrasted to $M$. guttatus. Houle (1992) has demonstrated for a number of models of selection that the $\mathrm{CV}_{\mathrm{G}}$ has greater predictive power of the ability of the population to respond to selection than heritability itself.
Fenster \& Ritland (1992) also found greatly reduced genetic variation in $M$. micranthus relative to $M$. guttatus in their survey of cpDNA restriction fragment length polymorphisms and 13 presumptive isozyme loci. Their data indicate that most of the molecular variation in $M$. micranthus is distributed among populations suggesting that founder effects and bottlenecks are common events in the histories of $M$. micranthus populations. Many factors may be responsible for different levels of genetic variation for the floral traits between the two species including differences in mutation and migration rates as well as differences in history of selection. Relatively high levels of genetic variation in some characters (e.g. date of first flower in population 301) suggest that loss of genetic variation through drift or lower levels of mutation are not responsible for the reduced levels of genetic variation for the floral characters. Lower variation may reflect the fact that reproductive success in a selfer is largely determined by female reproductive success and floral characters thus experience uniform selective pressures. In contrast, higher levels of genetic variation for floral traits in $M$. guttatus may reflect differential selective pressures on male and female reproductive functions or temporal and spatial variability in selective pressures due to pollinator availability (C. B. Fenster \& K. Ritland, unpublished data). 

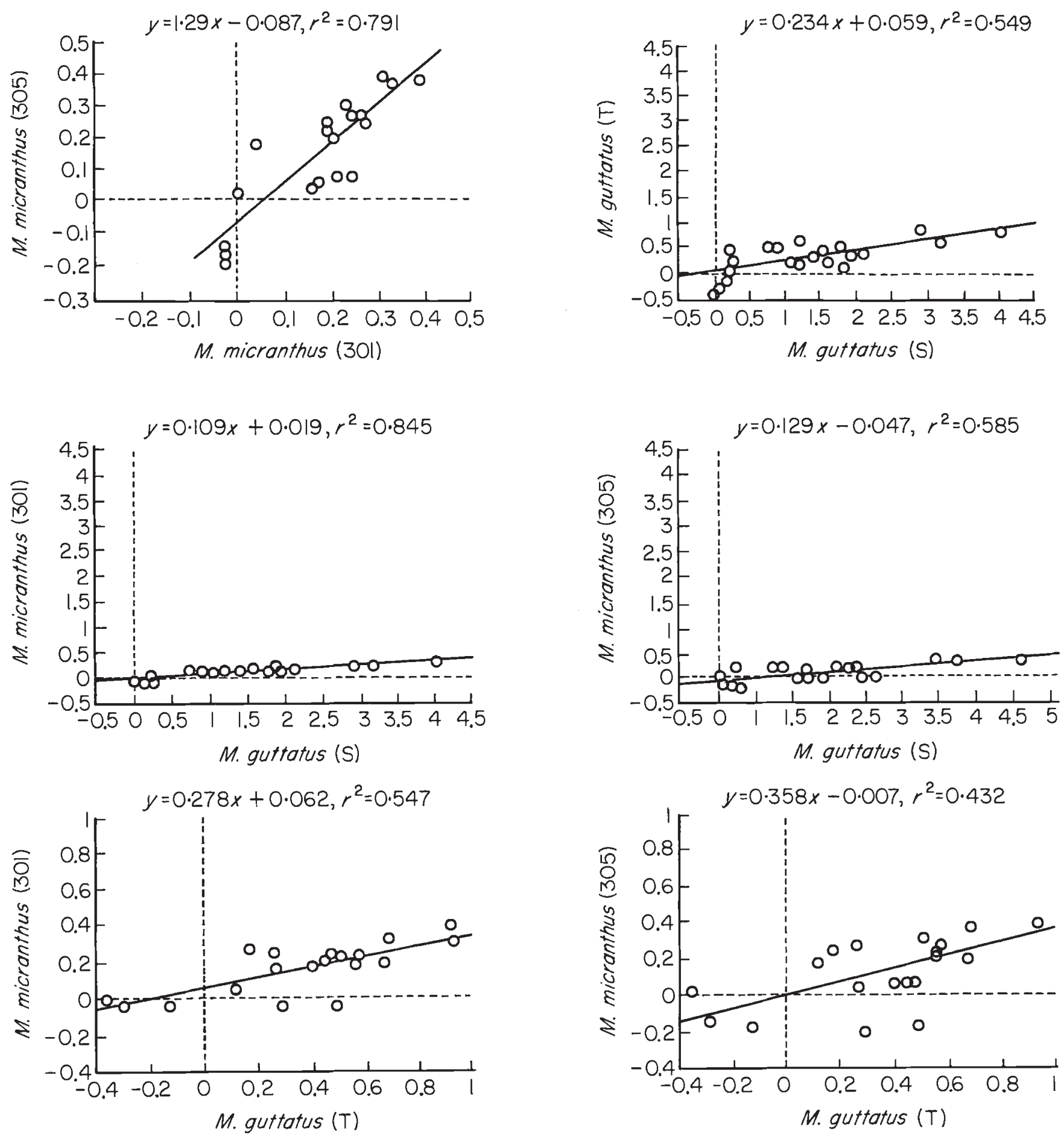

Fig. 1 All pairwise regressions of genetic variance-covariance matrices among two $M$. micranthus and two $M$. guttatus populations. The variance-covariance matrices are derived from the variance and covariance of family means for $M$. micranthus and represent the additive variance-covariance for $M$. guttatus. The dotted lines represent the $x$-and $y$-axes through the origin.

\section{Constraints to the response to selection}

Many characters in both species showed significant positive genetic correlations and therefore could not be independently altered by selection (Falconer, 1981).
This is not true for any population regarding correlations between either corolla length or width and stigma-anther separation. This indicates that for the range of variation observed in these populations 
reducing either measurement of corolla size will not necessarily reduce the degree of herkogamy.

One $M$. micranthus and both $M$. guttatus populations exhibited genetic variation for date of first flowering. Our results correspond to other studies which have also observed genetic variation for initial day of flowering (Lawrence, 1963; Carey, 1983; Pors \& Werner, 1989; but see Kelly, 1993). Guerrant (1988) has suggested that an increased level of autogamy may evolve as a correlated response to selection favouring earlier maturation of the plant and more rapid development of floral buds. While the S population of $M$. guttatus showed strong positive correlations between most floral characters and the date of first flower, no population showed a significant genetic correlation between stigma-anther separation and date of first flowering. Similarly, there was no correlation between date of first flowering and autogamous seedset. These results are consistent with those of an earlier study which observed no correlation between herkogamy and flowering time (Macnair \& Cumbes, 1989). It therefore appears that herkogamy can be maintained even under conditions favouring more rapid maturation of individual plants.

\section{Evolutionary consequences}

We found that population S of M. guttatus had significantly higher heritabilities relative to the $\mathrm{T}$ population. Other studies have also documented differences in heritability among populations (Bradshaw, 1984; Ashraf et al., 1986; Mitchell-Olds, 1986; Roff \& Mousseau, 1987; and equivocal data in Shaw \& Billington, 1991). The genetic correlations among floral traits associated with size observed here and in $\mathrm{F}_{2}$ segregants of crosses between Mimulus species (Macnair \& Cumbes, 1989; Fenster \& Ritland, 1994) are uniformly positive. However, casual comparisons among populations with respect to their genetic correlation matrices also reveal differences within species. In $M$. guttatus for instance, the $\mathrm{S}$ and $\mathrm{T}$ populations differ with respect to their correlations between all floral characters and date of first flower. They also differ in the genetic correlations involving stigma-anther separation; in the S population, smaller separations are associated with shorter pistils whereas smaller separations are associated with taller stamens in the $T$ population. However, with the exception of date of first flower all other elements show strong positive relationships among the populations. Other studies similarly have observed proportionality among genetic variance-covariance matrices (Arnold, 1981; Lofsvold, 1986; Kohn \& Atchley, 1988; Wilkinson, et al., 1990) while others have not (Falconer,
1960; Berven, 1982). Our results suggest that although amounts of genetic variation differ among populations, the overall trajectory of trait evolution for those floral characters that are associated with size should be similar in Mimulus.

\section{Acknowledgements}

D. E. Gill, G. S. Wilkinson, J. H. Willis and two anonymous reviewers provided useful comments on earlier versions of this manuscript. Initial seed collections from the field were made while C. B. Fenster was a post-doctoral fellow with $\mathrm{K}$. Ritland. We are grateful for laboratory assistance provided by $\mathrm{T}$. Cannizzaro, $\mathrm{R}$. Gilbert, S. Mok, D. Ntuyen, I. Otero, J. Park, A. Parker and M. Sanchez. Computer time for this project was supported in full through the facilities of the Computer Science Center at the University of Maryland. This is scientific article number A-6544, contribution number 8755 from the Maryland Agricultural Experiment Station, Department of Botany.

\section{References}

ARNOLD, S. J. 1981. Behavioral variation in natural populations. I. Phenotypic, genetic and environmental correlations among chemoreceptive responses to prey in the garter snake, Thamnophis elegans. Evolution, 35, 489-509.

ARnold, S. J. 1992. Constraints on phenotypic evolution. Am. Nat., 140, S85-S107.

ASHRAF, M., MCNEILLY, T. AND BRADSHAW, A. D. 1986. Tolerance to sodium chloride and its genetic basis in natural populations of grass species. New Phytol., 103, 725-734.

BARRETT, S. C. H. 1988. Evolution of breeding system in Eichhornia (Pontederiaceae): a review. Ann. Mo. Bot. Gard., 75, 741-760.

BARRETT, S. C. H., KOHN, J. R. AND CRUZAN, M. B. 1992. Experimental studies of mating-system evolution: the marriage of marker genes and floral biology. In: Wyatt, R. (ed.) Ecology and Evolution of Plant Reproduction, pp. 192-230. Chapman and Hall, New York.

BARRETT, S. C. H. AND SHORE, J. S. 1987. Variation and evolution of breeding systems in the Turnera ulmifolia L. complex (Turneraceae). Evolution, 41, 340-354.

BECKER, w. A. 1975. Manual of Quantitative Genetics, 3 rd edn. Washington State University Press, Pullman.

BERVEN, K. A. 1982. The genetic basis of altitudinal variation in the wood frog Rana sylvatica. I. An experimental analysis of life history traits. Evolution, 36, 962-983.

BODMER, W. F. AND PARSONS, P. A. 1962. Linkage and recombination in evolution. Adv. Gen., 11, 1-100.

BRADSHAW, A. D. 1984. The importance of evolutionary ideas in ecology - and vice versa. In: Shorrocks, B. (ed.) Evolutionary Ecology, pp. 1-25. Blackwell Scientific Publications, Oxford. 
CAREY, K. 1983. Breeding system, genetic variability, and response to selection in Plectritis (Valerianaceae). Evolution, 37, 947-956.

CHARLESWORTH, B. 1984. The evolutionary genetics of life histories. In: Shorrocks, B. (ed.) Evolutionary Ecology, pp. 117-133. Blackwell Scientific Publications, Oxford.

COWLEY, D. E. AND ATCHLEY, W. R. 1992. Comparison of quantitative genetic parameters. Evolution, 46, 1965-1967.

DARWIN, c. 1859. The Origin of Species by Means of Natural Selection, or the Preservation of Favoured Races in the Struggle for Life. John Murray, London.

DOLE, J. A. 1990. Role of corolla abscission in delayed selfpollination of Mimulus guttatus (Scrophulariaceae). Am.J. Bot., 77, 1505-1507.

DOLE, J. A. 1992. Reproductive assurance mechanisms in three taxa of the Mimulus guttatus complex (Scrophulariaceae). Am. J. Bot., 79, 650-659.

DOLE, J. AND RITLAND, K. 1993. Inbreeding depression in two Mimulus taxa measured by multigenerational changes in the inbreeding coefficient. Evolution, 47, 361-373.

DUDASH, M. R. AND RITLAND, K. 1991. Multiple paternity and self-fertilization in relation to floral age in Mimulus guttatus (Scrophulariaceae). Am. J. Bot., 78, 1746-1753.

FALCONER, D. S. 1960. Selection of mice for growth on high and low planes of nutrition. Genet. Res., 1, 91-113.

FALCONER, D. S. 1981. Introduction to Quantitative Genetics. Longman, London.

FENSTER, C. B. AND BARRETT, S. C. H. 1994. Inheritance of matingsystem modifier genes in Eichhornia paniculata (Pontederiaceae). Heredity, 72, 433-445.

FENSTER, C. B. AND RITLAND, K. 1992. Chloroplast DNA and isozyme diversity in two Mimulus species (Scrophulariaceae) with contrasting mating systems. Am. J. Bot., 79, 1440-1447.

FENSTER, C. B. AND RITLAND, K. 1994. The quantitative genetics of mating system divergence in the yellow monkeyflower species complex. Heredity, 73 , in press.

GUERRANT, E. O., Jr 1988. Heterochrony in plants: the intersection of evolution, ecology and ontogeny. In: McKinney, M. L. (ed.) Heterochrony in Evolution, pp. 61-84. Plenum Press, New York and London.

HAUPTLI, H. AND JAIN, S. 1985. Genetic variation in outcrossing rate and correlated floral traits in a population of grain amaranth (Amaranthus cruentus L.). Genetica, 66, 21-27.

HOLTSFORD, T. P. AND ELLSTRAND, N. C. 1992. Genetic and environmental variation in floral traits affecting outcrossing rate in Clarkia tembloriensis (Onagraceae). Evolution, 46, 216-255.

HOULE, D. 1992. Comparing evolvability and variability of quantitative traits. Genetics, 130, 195-204.

JAIN, S. K. 1976. The evolution of inbreeding in plants. Ann. Rev. Ecol. Syst., 7, 469-495.

KELLY, C. A. 1993. Quantitative genetics of size and phenology of life-history traits in Chameacrista fasciculata. Evolution, 47, 88-97.

KLEIN, T. W., DEFRIES, J. C. AND FINKBEINER, C. T. 1973. Heritability and genetic correlation: standard errors of estimates and sample size. Behav. Genet., 3, 355-364.
KOHN, L. A. P. AND ATCHLEY, W. R. 1988. How similar are genetic correlation structures? Data from mice and rats. Evolution, 42, 467-481.

LANDE, R. AND ARNOLD, S. J. 1983. The measurement of selection on correlated characters. Evolution, 37, 1210-1226.

LAWRENCE, C. W. 1963. Genetic studies on wild populations of Melandrium. II. Flowering time and plant weight. Heredity, 18, 149-163.

LLOYD, D. G. 1965. Evolution of self-compatibility and racial differentiation in Leavenworthia (Cruciferae). Contr. Gray Herb., 195, 3-134.

LLOYD, D. G. 1979. Some reproductive factors affecting the selection of self-fertilization in plants. Am. Nat., 113, 67-79.

LOFSVOLD, D. 1986. Quantitative genetics of morphological differentiation in Peromyscus. I. Test of the homogeneity of genetic covariance structure among species and subspecies. Evolution, 40, 559-573.

LOVELESS, M. D. AND HAMRICK, J. L. 1984. Ecological determinants of genetic structure in plant populations. Am. Rev. Ecol. Syst., 15, 65-95.

MACNAIR, M. R. AND CUMBES, Q. L. 1989. The genetic architecture of interspecific variation in Mimulus. Genetics, 122, 211-222.

MITCHELL-OLDS, T. 1986. Quantitative genetics of survival and growth in Impatiens capensis. Evolution, 40, 107-116.

MUNZ, P. A. AND KECK, D. D. 1959. A California Flora. University of California Press, Berkeley and Los Angeles, CA.

OLMSTEAD, R. G. 1989. Phylogeny, phenotypic evolution and biogeography of the Scutellaria angustifolia complex: inference from morphological and molecular data. Syst. Bot., 14, 320-338.

PORS, B. AND WERNER, P. A. 1989. Individual flowering time in goldenrod (Solidago canadensis): field experiment shows genotype more important than environment. Am. J. Bot., 76, 1681-1688.

RITLAND, C. AND RITLAND, K. 1989. Variation of sex allocation among eight taxa of the Mimulus guttatus species complex (Scrophulariaceae). Am. J. Bot., 76, 1731-1739.

RITLAND, K. 1990. Inferences about inbreeding depression based on changes in the inbreeding coefficient. Evolution, 44, 1230-1241.

RITLAND, K. AND GANDERS, F. R. 1987. Crossability in Mimulus guttatus in relation to components of gene fixation. Evolution, 41, 772-786.

ROFF, D. A. AND MOUSSEAU, T. A. 1987. Quantitative genetics and fitness: lessons from Drosophila. Heredity, 58, 103-118.

RoLlins, R. C. 1963. The evolution and systematics of Leavenworthia (Cruciferae). Contr. Gray Herb., 192, 3-198.

SCHOEN, D. J. 1982. Genetic variation and the breeding system of Gilia achilleifolia. Evolution, 36, 361-370.

SHAW, R. G. 1991. The comparison of quantitative genetic parameters between populations. Evolution, 45, 143-151.

SHAW, R. G. 1992. Comparison of quantitative genetic parameters: reply to Cowley and Atchley. Evolution, 46, 1967-1969.

SHAW, R. G. AND BILLINGTON, H. L. 1991. Comparison of variance components between two populations of Holcus lanatus: a reanalysis. Evolution, 45, 1287-1289. 
SHORE, J. S. AND BARRETT, S. C. H. 1990. Quantitative genetics of floral characters in homostylous Turnera ulmifolia var. angustifolia Wild. (Turneraceae). Heredity, 64, 105-112.

STEBbins, G. L. 1950. Variation and Evolution in Plants. Columbia University Press, London.

StEeves, T. A. AND susseX, I. M. 1989. Patterns of Plant Development. Cambridge University Press, Cambridge.

WILKINSON, G. S., FOWLER, K. AND PARTRIDGE, L. 1990. Resistance of genetic correlation structure to directional selection in Drosophila melanogaster. Evolution, 44, 1990-2003.

wiLlis, J. H. 1991. The Role of Inbreeding Depression in the Evolution of Two Partially Self-fertilizing Populations of Mimulus guttatus. Ph.D. Thesis, University of Chicago.
WILLIS, J. H. 1993. Effects of different levels of inbreeding on fitness components in Mimulus guttatus. Evolution, 47, 864-876.

WRIGHT, A. J. AND COCKERHAM, C. C. 1985 . Selection with partial selfing. I. Mass selection. Genetics, 109, 585-597.

WRight, s. 1968. Evolution and the Genetics of Populations, vol. 1, Genetic and Biometric Foundations. The University of Chicago Press, Chicago.

WRIGHT, s. 1969. Evolution and the Genetics of Populations, vol. 2, The Theory of Gene Frequencies. The University of Chicago Press, Chicago.

WYATT, R. 1988. Phylogenetic aspects of the evolution of selfpollination. In: Gottlieb, L. D. and Jain, S. K. (eds) Plant Evolutionary Biology, pp. 109-131. Chapman and Hall, London. 